\title{
The Frequency of Hypothyroidism in Middle Aged Women Suffering From Headache in Diyala Governorate Zeina F Fuad (Msc) ${ }^{1}$, Mohammed M Kamil (FICMS) ${ }^{2}$ and Noor M Abdulkader(HDCB) ${ }^{3}$ \\ Abstract
}

Background:The previous researches show that the hypothyroidism occurs in approximately $1-2 \%$ of women and $0.1 \%$ of men and is characterized by a TSH level above the normal reference range and a $\mathrm{T} 4$ level below the reference range. This percentage indicate that: women have ten times the risk of hypothyroidism as men, with the difference became significant above the age of 34 years. Hypothyroidism may very easily be missed due to the similarity between the symptoms of hypothyroidism and that of menopause.Many middle-age women complained from headache whether it is tension headache or migraine and since headache is one of the symptoms of hypothyroidism, so there will be many cases of misdiagnosed hypothyroidism. This study estimates thyroid function test for those women to shed a light for the frequency of hypothyroid women.

Objective: To current study screening middle- aged women suffering from headache by thyroid function test to treat these women properly and not only treat the headache as a separate complain

Patients and Methods: Three hundred (300) women aged between $35-55$ years with headache included in this study, their chief complain is only headache, they have no other medical conditions or chronic diseases. They were divided in to two groups; the first group aged from (35- 45 years), while the second one aged from (46-55 years). Three hundred (300) healthy women aged between (35-55 years) are screened for TFT (thyroid function test) as a control group were divided in to two groups; the first group aged from (35-45 years) while the second group aged between (46-55 years). Thyroid function test (TSH, T3, and T4) were done for all groups.

Results: There are 53(17.6\%) women in patients group have high TSH with low T3 and T4 which means that they have overt hypothyroidism and 17(5.7\%) women in the same group have only high TSH which means that they have (subclinical) hypothyroidism, while 230 (76.7\%) women have normal thyroid function test. This means that: the total number of hypothyroid women is 70 (23.3\%) which is regarded as high percentage.

Conclusion:There is a high percentage of women suffering from headache having hypothyroidism so thyroid function test should be done for all middle-aged women with from headache.

Key words: Hypothyroidism, headache, thyroid function test.

Corresponding Author: zenafaroog@yahoo.com

Received: $15^{\text {th }}$ October 2017

Accepted: $24^{\text {th }}$ January 2018

https://doi.org/10.26505/DJM.

\footnotetext{
${ }^{1}$ Department of Biochemistry - College of Medicine- Diyala University- Iraq.

${ }^{2,3}$ Baqubah Teaching Hospital-Diyala Governorate- Baquba City- Iraq.
} 


\section{Introduction}

Hypothyroidism is a common endocrine disorder resulting from deficiency of thyroid hormone. In iodine sufficient area, autoimmune thyroid disease (Hashimoto disease) is the most common cause of hypothyroidism; worldwide, iodine deficiency remains the foremost cause.

Hypothyroidism is mostly occurred in women more than men [1,2], it is presented in women between $40-50$ years of age. It may occur during the years of menopause and symptoms of hypothyroidism are often ignored during the early stages by both doctors and patients [3,4]. The Association of Clinical Biochemistry, British Thyroid Association and British Thyroid Foundation state in the 'UK Guidelines for the Use of Thyroid Function Tests', "The prevalence of spontaneous hypothyroidism is 1-2\%" (approximately 2 in every 100 people) but some researches showed that the rate is higher than recorded value. One important symptom of hypothyroidism is the pain as pressure headaches, migraines, back pain, wrist pain (Carpal Tunnel Syndrome), and foot pain (Burning Feet Syndrome) [5].

For unexplained reasons, hypothyroidism afflicts women, especially those aged between 35 and 60 . Researches show that one in eight women aged between 35 and 65 years and one in five women older than 65 years have some form of thyroid dysfunction [6]. Hyperthyroidism results from the body producing excess amount of thyroid hormones, but the most common is the deficiency of producing these hormones (hypothyroidism). About 26 percent of women in or near perimenopause are diagnosed with hypothyroidism[6].

A strong relation has been recorded between hypothyroidism and daily persistent headache and resistant migraine. Researchers have concluded that coexisting conditions can affect each other in several ways, including how they progress and the amount of time it takes to diagnose them and find effective treatments. In addition, it's been shown that coexisting conditions may play a role in headaches becoming and remaining daily or near-daily events $[7,8]$. In some cases, the treatment of hypothyroidism increasing the response of migraine to treatment in a dramatic way. [8].

Previous researches concluded, "Subclinical (undetected) hypothyroidism may be associated with the development of new daily persistent headaches. Also, hypothyroidism may be associated to refractoriness to treatment in patients with primary (primary headaches are headaches that are not caused by another disease or condition) headaches, e.g. Migraine[7,8].

Thyroid and other hormones of endocrine origin can play an obvious role in the development of migraine and headache and their resistance to treatment $[7,8,9]$.

Hypothyroidism is another cephalalgia with an endocrinological cause after menstrual cephalalgia[10]. 


\section{Patients and Methods}

Three hundred (300) women aged between $35 \quad-55$ years with headache attending the consultation room of neurology in Baquba teaching hospital from the first of April 2015 to the first of December 2015, they were divided in to two patient groups; the first group aged from (35- 45 years) while the second one aged from (46-55 years). Three hundred (300) healthy women aged between (35-55 years) screened for TFT (thyroid function test) as a control group were divided in to two groups; the first group aged from (3545 years) while the second group aged between (46-55 years). Thyroid function tests (Thyroid stimulating hormone (TSH), Triiodothyronine (T3) and Thyroxine (T4) were done. Full medical history is taken, all women are only complained from headache, they have no other medical conditions or chronic diseases. Venous blood samples were taken from those women and collected in tubes and left in the room for 10-15 minutes then separated by centrifuge for 10 minutes to obtain the serum which is estimated for TSH, T3 and T4 by Cobas e 411(Roche Diagnostics GmbH, Germany 2009), in the biochemistry department in the Baquba teaching hospital, which depends on the sandwich principle for high molecular weight analytes and the concentrations of these analytes are obtained by electrochemiluminescent processes (ECL).

\section{Statistical Analysis}

Results were statistically analyzed by SPSS 11.5 for Windows. Results considered significant or non-significant when $\mathrm{P}>$ or $<0.05$ respectively.

\section{Results}

Table (1): Table 3-1 Thyroid function test in patients group.

\begin{tabular}{|c||c|c||c|c||}
\hline $\begin{array}{c}\text { Thyroid function } \\
\text { test }\end{array}$ & $\begin{array}{c}\text { Hypothyroidism } \\
\uparrow \mathrm{TSH} \downarrow \mathrm{T}_{3} \downarrow \mathrm{T}_{4}\end{array}$ & $\begin{array}{c}\text { Subclinical } \\
\text { hypothyroidism } \\
\uparrow \mathrm{TSH} \leftrightarrow \mathrm{T}_{3} \leftrightarrow \mathrm{T}_{4}\end{array}$ & $\begin{array}{c}\text { Abnormal thyroid } \\
\text { function test } \\
\text { (total) }\end{array}$ & $\begin{array}{c}\text { Normal thyroid } \\
\text { function test } \\
\leftrightarrow \mathrm{TSH} \leftrightarrow \mathrm{T}_{3} \leftrightarrow \mathrm{T}_{4}\end{array}$ \\
\hline \hline Number of patients & 53 & 17 & 70 & 230 \\
\hline \hline Frequency $(\%)$ & $17.6 \%$ & $5.7 \%$ & $23.3 \% *$ & $76.7 \%$ \\
\hline
\end{tabular}

Table(1) showed that there are 53(17.6\%) women have high TSH with low T3 and T4 which means that they have overt hypothyroidism and 17(5.7\%) women have only low TSH which means that they have subclinical hypothyroidism, while 230
(76.7\%) women have normal thyroid function test. The total number of hypothyroid women is $70(23.3 \%)$ which is regarded as high percentage. 
The Frequency of Hypothyroidism in Middle Aged Women Suffering From Headache in Diyala Governorate

Zeina F Fuad

Table (2): Thyroid function test in control group.

\begin{tabular}{|c|c|c|c|c|}
\hline $\begin{array}{c}\text { Thyroid function } \\
\text { test }\end{array}$ & $\begin{array}{c}\text { Hypothyroidism } \\
\uparrow \mathrm{TSH} \downarrow \mathrm{T}_{3} \downarrow \mathrm{T}_{4}\end{array}$ & 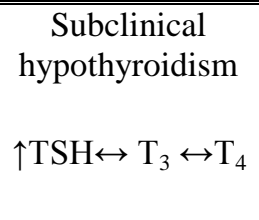 & $\begin{array}{l}\text { Abnormal thyroid } \\
\text { function test } \\
\text { (total) }\end{array}$ & $\begin{array}{l}\text { Normal thyroid } \\
\text { function test } \\
\leftrightarrow \mathrm{TSH} \leftrightarrow \mathrm{T}_{3} \\
\leftrightarrow \mathrm{T}_{4}\end{array}$ \\
\hline Number of patients & 4 & 9 & 13 & 287 \\
\hline Frequency (\%) & $1.3 \%$ & $3 \%$ & $4.3 \% *$ & $95.6 \%$ \\
\hline
\end{tabular}

Figure (2) Comparison of percentage of Vitamin D3 concentration among Thalassemia patients and control group.

Table (2) showed that there are 13 have normal thyroid function test.P value women have hypothyroidism which is significant (0.001) when we compare represent $4.3 \%$, while 287 women $(95.6 \%) \quad$ between two groups.

Table (3): Thyroid function test in patients group according to the age.

\begin{tabular}{|c|r||c||c||c||}
\hline Age group (year & No. & $\begin{array}{c}\text { Hypothyroidism } \\
\uparrow \mathrm{TSH} \downarrow \mathrm{T} 3 \downarrow \mathrm{T} 4\end{array}$ & $\begin{array}{c}\text { Subclinical hypothyroidis } \\
\uparrow \mathrm{TSH} \leftrightarrow \mathrm{T} 3 \leftrightarrow \mathrm{T} 4\end{array}$ & $\begin{array}{c}\text { Normal thyroid functi } \\
\text { test } \\
\leftrightarrow \mathrm{TSH} \leftrightarrow \mathrm{T} 3 \leftrightarrow \mathrm{T} 4\end{array}$ \\
\hline \hline $35-45$ & 198 & $37(18.7 \%)$ & $8(4 \%)$ & $153(77.3 \%)$ \\
\hline \hline $46-55$ & 102 & $16(15.7 \%)$ & $9(8.8 \%)$ & $77(75.5 \%)$ \\
\hline \hline total & 300 & $53(17.6 \%)$ & $17(5.7 \%)$ & $230(76.7 \%)$ \\
\hline
\end{tabular}

Table (3) showed that the percentage of hypothyroidism in the age group (46-55 years) is $24.5 \%$ which is slightly higher than that in the age group (35-45 years).

Table (4): Thyroid function test in control group according to the age.

\begin{tabular}{|c||c||c||c||c||}
\hline $\begin{array}{c}\text { Age group } \\
\text { (years) }\end{array}$ & No. & Hypothyroidism & Subclinical hypothyroidism & $\begin{array}{c}\text { Normal thyroid function } \\
\text { test }\end{array}$ \\
& $\uparrow \mathrm{TSH} \downarrow \mathrm{T} 3 \downarrow \mathrm{T} 4$ & $\mathrm{TSH} \leftrightarrow \mathrm{T} 3 \leftrightarrow \mathrm{T} 4$ & $\leftrightarrow \mathrm{TSH} \mathrm{T} 3 \leftrightarrow \mathrm{T} 4$ \\
\hline \hline $35-45$ & 131 & $1(0.76 \%)$ & $4(3 \%)$ & $126(96.1 \%)$ \\
\hline \hline $46-55$ & 169 & $3(1.77 \%)$ & $5(2.9)$ & $161(95.2)$ \\
\hline \hline total & 300 & $4(1.3 \%)$ & $9(3 \%)$ & $287(95.6 \%)$ \\
\hline
\end{tabular}

Table (4) showed that the frequency of subclinical hypothyroidism is more than that of overt hypothyroidism and the frequency of hypothyroidism in the age group (46-55 years) is more than that in the age group (35-45 years).

\section{Discussion}

Hypothyroidism is found to be an important predisposing factor to the 
development of chronic headache (migraine and tension-type headache) and this agrees with previous studies[11,12,13,14,15,16]. The frequency of subclinical and overt hypothyroidism in the patients group was also higher than that reported in the general population. This agrees with previous studies established in North India[17,18]. Our study showed that $23.3 \%$ of middle aged women suffering from headache have hypothyroidism and this agrees with previous study showed that approximately one-third of the patients evaluated reported headache attributed to hypothyroidism. [10].

Our study is in a good agreement with other studies that show high percentage of hypothyroidism in women near perimenopause age[6,19,20].

\section{Conclusions}

There is a high percentage of women with headache having hypothyroidism so thyroid function test should be done for all middleaged women suffering from headache.

\section{References}

[1] Xin Sun, Zhongyan Shan, Weiping Teng. Effects of Increased Iodine Intake on Thyroid Disorders. Endocrinol Metab (Seoul). 2014 Sep; 29(3): 240-247.

[2] Ma T, Guo J, Wang F. The epidemiology of iodine-deficiency diseases in China. Am J Clin Nutr. 1993;57(2 Suppl):264S-266S.

[3] Love, Susan M.D. Menopause and Hormone Book. New York: Three Rivers Press, 2003.
[4]McDermott MT. In the clinic. Hypothyroidism. Ann Intern Med. 2009; 151(11): ITC61.

[5] Vanderpupm MPJ, Tunbridge WMG. The incidence of thyroid disorders in the community; a twenty-years follow up of the Whickham survey. Clin Endocrinol 1995; 43: 55-68.

[6] Massoudi, M. S. Prevalence of thyroid antibodies among healthy middle-aged women. Findings from the thyroid study in healthy women. Annals of Epidemiology 1995; 5 (3), 229-233.

[7] Bigal, Marcelo E, Sheftell, Fred D, Rapoport, Alan M, Tepper, Stewart J. The Woman with the Never Ending Headaches. from: Purdy, R. Allan, MD, FRCPC; Rapoport, Alan, MD; Sheftell, Fred, MD; Tepper, Stewart, MD. "Advanced Therapy of Headache," Second Edition. B.C. Decker. 2004.

[8] Bigal, Marcelo E., Sheftell, Fred D., Rapoport, Alan M., Tepper, Stewart J., Lipton, Richard B. Chronic Daily Headache: Identification of Factors Associated with Induction and Transformation. The Journal of Head and Face Pain. 2002; 42 (7), 575-581.

[9]Spierings, Egilius L.H. Daily Migraine with Visual Aura Associated with an Occipital Arteriovenous Malformation. Headache: The Journal of Head and Face Pain. 2001; 41 (2), 193-197.

[10]Moreau T, Manceau E, GiroudBaleydier F. Headache in hypothyroidism. Prevalence and outcome under thyroid hormone therapy. Cephalalgia 1998; 18: 687-689. 
[11] Trauninger A, Leél-Össy E, Kamson DO. Risk factors of migraine-related brain white matter hyperintensities: an investigation of 186 patients. Headache Pain. 2011;12(1):97-103.

[12] Garber JR, Cobin RH, Garib H. Clinical practice guidelines for hypothyroidism in adults: cosponsored by the American Association of Clinical Endocrinologists and the American Thyroid Association. Endocrine Practice. 2012;18(6):988-1028.

[13]Brent GA and Davies TF. Hypothyroidism and thyroiditis. In: Melmed S, Polonsky KR, Larsen PR, Kronenberg HM, eds. Williams Textbook of Endocrinology. 12th ed. Philadelphia, Pa: Saunders Elsevier; 2011: chap 13.

[14] Lisotto C. The comorbidity between migraine and hypothyroidism. The Journal of Headache and Pain. 2013;14(Suppl 1): P138. doi:10.1186/1129-2377-14-S1-P138. [15] Martin, Andrew. Headache Disorders May Be a Risk Factor for the Development of New Onset Hypothyroidism. Headache: The Journal of Head and Face Pain. 2016; DOI: 10.1111/head.12943.

[16] Deborah E. Tepper, Stewart J. Tepper, Fred D. Sheftell, Marcelo E. Bigal.
Headache attributed to hypothyroidism. Springer nature. August 2007, Volume 11, Issue 4, pp 304-309.

[17] Unnikrishnan AG, Menon UV. Thyroid disorders in India: An epidemiological perspective. Indian journal of endocrinology and metabolism. $2011 \mathrm{Jul}$ $1 ; 15(6): 78$.

[18]Usha MV, Sundaram KR, Unnikrishnan AG, Jayakumar RV, Nair V, Kumar H. High prevalence of undetected thyroid disorders in an iodine sufficient adult south Indian population. Journal of the Indian Medical Association. 2009 Feb; 107(2):72-7.

[19] Freeman EW, Sammel MD, Lin H et al: Symptoms in the Menopausal Transition: Hormone and Behavioral Correlates. Obstet Gynecol. 2008 Jan;111(1):127-136.

[20] Schindler, A. Thyroid function and postmenopause. Gynecol Endocrinol. 2003 Feb;17(1):79-85. 